\title{
Modern Information Technologies and Language Animation in Foreign Languages Teaching
}

\author{
Angelina Bagateeva \\ Philology Department \\ Kazan Federal University \\ Naberezhnye Chelny Institute \\ Naberezhnye Chelny, Russia \\ AOBagateeva@kpfu.ru \\ Elmira Vildanova \\ Philology Department \\ Kazan Federal University \\ Naberezhnye Chelny Institute \\ Naberezhnye Chelny, Russia \\ carinavil@rambler.ru

\section{Irina Strahova} \\ Philology Department \\ Kazan Federal University \\ Naberezhnye Chelny Institute \\ Naberezhnye Chelny, Russia \\ istrahova@yandex.ru
}

\author{
Alsu Aydarova \\ Philology Department \\ Kazan Federal University \\ Naberezhnye Chelny Institute \\ Naberezhnye Chelny, Russia \\ alsu-irek@mail.ru \\ Natalya Koroleva \\ Philology Department \\ Kazan Federal University \\ Naberezhnye Chelny Institute \\ Naberezhnye Chelny, Russia \\ koroleva_ne@mail.ru \\ Tatyana Mazaeva \\ Philology Department \\ Kazan Federal University, \\ Naberezhnye Chelny Institute \\ Naberezhnye Chelny, Russia \\ mtv-mazaika@mail.ru
}

\begin{abstract}
The article focuses on the study of cutting-edge mobile technologies and information and communicative technologies (ICT) and their application in teaching a wide range of subjects in higher education in general and a foreign language in particular. The study has shown the common teaching methods integrally embrace the ICT application: a method of passing on new knowledge (based on digital education Internet resources which facilitate a massive access to learning materials irrespective of temporal and spatial boundaries); a method of building skills (ICT application enables to create a reusable database of educational and teacher training resources and have a regular feedback, which enhances the acquisition of the material under study); a method of building new knowledge based on the experience of ICT application of the above mentioned models. The authors pinpoint the definition of the term "mobile education" from their own perspective and offer the checklist of the most efficient mobile technologies and ICT used in teaching techniques (e-mail, blog-technologies, wikitechnologies, podcasts, web-forums, e-dictionaries, information and reference internet resources, video communication means, etc.) which aim at the development of foreign communicative competence of university students. The introduction of ICT into the education process while teaching a foreign language has a beneficial influence on the achievement of the main goal of
\end{abstract}

modernization in education, which is supposed to create quality education.

Keywords: information and communicative technologies, teaching foreign languages, generation $Z$, language animation

\section{INTRODUCTION}

The current stage of development of Russia in terms of political, economic and social changes deems it necessary to improve the quality and accessibility of education as well as boosting academic mobility and its integration into the world community.

The process of rapid implementation of new ICT into education process builds new authentic teaching techniques in foreign languages. There are different approaches to the definition of the notion of ICT [1]. In science literature one can come across the following terminology: "mobile education", "IT-education", "computer technologies in education", "new information technologies in education (NITeducation)", multimedia education technologies, etc.

Information and communicative technologies are a combination of objects, actions and regulations that mean to 
In connection with the rapid development of mobile prepare process and deliver information in personal, mass and industrial media. Mobile education is implemented with the aid of mobile technologies - mobile means of human interaction [2]. As far as teaching foreign languages is concerned, the following mobile technologies can be effectively applied: (e-mail, blog and wiki-technologies, podcasts, e-dictionaries, video communication means, navigators to name but a few.

The mainstream teaching technique in a foreign language for university students suggested honing reading skills [3], translation of technical texts and studying the scientific language syntax issues, which was prescribed by the federal national standard system. The contemporary techniques of foreign languages are based on the communicative approach [4] and embrace the application of various kinds of IT, which are conductive to democracy, open-mindedness and mobility.

The technology of mixed education is becoming more and more widespread in teaching a foreign language, since on the one hand it enables to organize the teacher's and a student's time to the max and on the other hand, makes the student easily involved into the education process and find it accessible.

Mixed education implies the application of mobile technologies and ICT in education process, and thus creates a favorable ground for effective language acquisition.

The notion "mixed education" can be defined as a fusion of formal conventional teaching aids (classroom work, the language course study) with non-conventional (the discussion of significant aspects of the material under study via e-mail and internet conferences). For another thing, it resembles the mixture of different methods of material representation (fulltime, electronic, online education and self-education) using techniques of knowledge management.

In mixed education environment the teacher has to skillfully combine classroom and extracurricular work of the student, challenge individual and team work, create online student support. Students, for their part, are to formulate the final goal of education and build their style of education and tactics to make further moves. The teacher and students are in close interaction, hence the education process is based on independent, beneficial, efficient and development-oriented approach.

\section{MethodS}

Methodology functions, related to a foreign language teaching, are methodology variants of these technologies in the development of speaking language skills and shaping social, cultural and intercultural competence of the students.

The efficiency of the academic process depends on a number of factors, the most critical of which involve the way of representation of the course structure and contents. Contemporary foreign educators resort to the term "teacher training design" to denote methods, principles and approaches to the formation, structuring and content-building of the academic course based on ICT. technologies and ICT, there is a growing attention to the teaching techniques aids of e-learning format. Meanwhile, it's vital to attend not only to the teaching techniques but to the academic process systematization. The traditional method of teaching a foreign language is a communicative one. The communicative cycle rests on the notion "building a situation, characterized by the information deficiency" (building the information gap). Thus, communicative approach to the structure and content-building of the course reflects the following stages: crucial environment for communication (building this environment), finding out information and defining a peculiar information gap, the acquisition of language material, relevant to the solution of the communicative task, communicative training, a comeback to the initial situations in this context.

A foreign language course, supported by ICT is the most effective way of building a foreign communicative competence among university students. At the same time, the most common ways of application of ICT in education are the application of a number of ICT tools based on different platforms or the application of a uniform academic platform which enables to integrate a range of ICT applications based on it.

The didactic ICT possibilities have been studied and delineated in detail by many scholars. It should be pointed out that common teaching methods integrally embrace the ICT application. The most efficient ones are the following methods:

- a method of passing on new knowledge. This model is based on digital education Internet resources which facilitate a massive access to learning materials irrespective of temporal and spatial boundaries. The downfall of this method is that the student is a passive recipient of information.

- a method of building skills. ICT application enables to create a reusable database of educational and teacher training resources and have a regular feedback, which enhances the acquisition of the material under study. The systematic application of this method taps ICT potential to the full extent and reconsiders the role of a teacher. The shortcomings of this method consist in the scant information competence of the teacher.

- a method of building new knowledge based on the experience of ICT application of the above mentioned models. Due to this method students are supposed to build the strategy to solve academic tasks on their own, have a critical appraisal of the information and analyze approaches to the solution of the tasks. The teacher's role consists in supervision and mentoring of the education process. This model makes the teacher highly accountable for the results achieved while devising learning materials. This method suggests high motivation, critical thinking, effective student cooperation. The motivation factors such as the ability to be consistent in studies, responsibility, ambition are the main tools for knowledge acquisition. The use of ICT in the process of learning a foreign language has 
the following advantages: appeal for the students to evoke interest in learning a foreign language, interactivity of educational materials; the possibility of adapting the educational process to the needs of each student. The demerits of this method in connection with ICT implementation are high demands to the information and communication culture of the university teaching staff.

\section{RESULTS AND DISCUSSION}

When talking about the learning process of modern youth, many researchers point out its significant differences from previous generations and primarily in psychological terms. For example, based on the views of the popular "generational theory" creators William Strauss and Neil Howe, it can be concluded that the first fully digital generation $\mathrm{Z}$ has a completely different, specific, if not naturally opposite, reaction to the classical methods of presentation of educational material, compared with that which was characteristic of previous generations [5]. In particular, in the article by A.V. Sapa it's noted that the generation $\mathrm{Z}$ which grew up during the period of active distribution of multimedia technologies is characterized by a completely different (so-called "clip") style of thinking, as a result of the continuously increasing information load. The image of their thoughts is fragmented, and in some matters, superficially [6], the representatives of this generation are able to perceive information quickly, but in small portions, and to be aware of it in the same way, they tend to get the result immediately without going into unnecessary details and not wasting time on laborious processing of the material. As psychological features the author also emphasizes progressive infantilization and introverted individualism, to a great extent, due to the influence of the virtual environment. Unresolved children's reactions to everything around and the active use of the possibility of unhindered care in a safe virtual reality from manifestations of an unattractive and often unsafe external world are also becoming quite typical manifestations of the behavior of modern youth. Therefore, it is quite difficult for them to apply the efforts necessary for mastering significant amounts of material in the classical organization of the educational process [7].

On the basis of this it is obvious that changes in the perception and thinking of students lead to a consistent transformation of learning process organization. From this point of view it seems quite logical to tune the virtual environment in which students spend much of their time for educational purposes, since the virtual (including educational) environment causes more positive associations among members of the digital generation, a greater degree of trust due to its familiarity and offers them ways of self-realization much larger than those that are possible in the framework of the "school method".

However, this process has a natural consequence of the fact that an increase in communication in a virtual environment inevitably entails a decrease in contacts in reality. Therefore, a distinctive feature for generation Z, as A.V. Sapa indicates, is also a preference for written (virtual) oral communication, the desire for voluntary social self-isolation.
In addition, it is impossible not to note another trend that plays a significant role in the educational process of a modern university: actively developing academic mobility due to globalization and migration processes. In this case, the growing number of groups with a multi-ethnic composition implies not only the ability of members of such a group to communicate with each other in a situation of real communication, but also the need for students to have intercultural competence, the role of their communicative culture increases significantly [8].

Communicating by means of the World Wide Web is an integral part of the educational process like exchanging information including online, watching serials for the youth and broadcasts for mastering the studied language $[9,10]$.

Under these conditions, as a possible alternative to a computer, the technique of language animation proposed by methodologists of Goethe Cultural Center [11] can be considered. The visualization, dramatization and dynamism used in it can serve as a kind of counterbalance to computer individualization and carry out a compensatory function with respect to increasing the amount of direct human communication.

Another important feature causing students' active interest in computer technologies in the educational process is the possibility of using game elements in the learning process. Many researchers agree that it is precisely the principle of pleasure and entertainment that is put at the forefront today and is becoming quite significant for modern students. In the case of the use of language animation the gaming component and the communicative situation are combined, and the term "animation" itself a priori implies the entertaining and emotional involvement of the participants in the process.

According to Russian researchers participation in the game allows to develop the ability to persuade, develop tact in relation to the communication partner, the ability to politely and kindly bring it to the desired results of negotiations or to resolve conflict situations [12], all of the above can be attributed to the method language animation. Thus, the inclusion in the educational process of the elements of language animation can be considered as a promising language strategy that meets the psychological characteristics of modern students, helps to optimize the educational process and increase its efficiency.

At present the process of student language training comes in different shapes and sizes. The changes during the English language learning are taking place in many leading technical universities of Russia. The innovations touch upon different aspects of education process ranging from the changes in classroom space organization and classroom equipment with advanced technical aids up to pilot tests in brand-new education technologies at practical classes and during the selfeducation of the students while using a great number of online-components and internet resources [13].

Multimedia technologies increase students' interest for independent work $[14,15]$. A multimedia e-learning system or a learning management system has been created for these 
purposes, in which both students and teachers have the opportunity to move effectively towards educational goals.

These systems are characterized by a high level of interactivity containing a great number of individual and group tasks and work in real time. The functioning of these systems is provided by the so-called "electronic platforms" (or on- line platforms), with which a teacher can create an environment and conditions for students' active learning.

The use of electronic means gives students the opportunity to choose their own ways of learning (the student works with ICT at a convenient time, in a convenient place and the number of tries and attempts that he needs) and the ability to control their own cognitive processes when organizing work during extracurricular time therefore the use of ICT increases students' motivation to learn a foreign language.

\section{SUMMARY}

The continuously increasing role of information technologies and a significant number of qualitatively new scientific achievements that have caused a natural transformation in all spheres of human activity, and the field of foreign language teaching is not an exception. Changes are manifested both at the level of modification of learning technologies and in relation to the psychological characteristics of the students themselves.

The use of ICT in education helps students to develop the ability to to plan and organize, evaluate and adjust their educational activities independently, focusing on results.

Students learn to make up their minds, make choices and take responsibility, develop skills and abilities while working in the information space, searching, selecting and analyzing information, presenting the result with the use of various modern technologies, thereby forming the necessary speech and socio-cultural competences.

However, when introducing innovative methods and technologies in the teaching of a foreign language, it is necessary to remember about the effectiveness of innovations being introduced into the educational process on the one hand, and on the other hand all innovations require a critical approach and comprehensive analysis.

\section{CONCLUSIONS}

Highly informative material which is due to ICTs increase students' motivation, stimulate their cognitive activity, and allow to solve many didactic tasks. Thus the foreground challenge in teaching university students a foreign language is the formation of students' communicative competence to solve professional tasks with the help of the studied foreign language.

The authors pinpoint the definition of the term "mobile education" from their own perspective and offer the checklist of the most efficient mobile technologies and ICT used in teaching techniques (e-mail, blog-technologies, wikitechnologies, podcasts, web-forums, e-dictionaries, information and reference internet resources, video communication means, etc.) which aim at the development of foreign communicative competence of university students.
The introduction of ICT into the education process while teaching a foreign language has a beneficial influence on the achievement of the main goal of modernization in education, which is supposed to create quality education, that contributes to the development of harmonious personality who will fit in the information domain and be knowledgeable in ITC as long as there is a surge in social demand of information community.

\section{REFERENCES}

[1] B. Chowdhury, M. Dungey, M. Kangogo, M. A. Sayeed, and V. volkov, "The changing network of financial market linkages: The Asian experience", International Review of Financial Analysis Bagateeva, A. O. Modern mobile and information communication technologies in teaching university students, Modern journal of language teaching methods, 2018, vol.8, is.11, pp. 254-259.

[2] A. K. Garayeva, E. P. Kartashova, G. F. Nizamutdinova, M. V. Zhuravleva, A. M. Gatiatullina, and et. al., "Information competence structure and content of the higher school students", Mediterranean Journal of Social Sciences, Rome-Italy, 2015, vol. 6, no. 2, S3, pp. 254259.

[3] A. I. Gazizova, "Formal and non-formal education means of mastering foreign language skills, The Social Sciences (Pakistan). 10 (6), 1324$1328,2015$.

[4] I. D. Zeynalova, "Specifics of educational process in College in the conditions of Informatization of education", Bulletin of sociopedagogical Institute, 2015, no. 4 (16), pp. 58-62.

[5] Ye. M. Ozhiganova, "The theory of generations by N. Khouv and V.Shtrausa. Opportunities for practical use", Business education in the knowledge economy, 2015, 1.

[6] A. V. Sapa, "Generation Z - generation era of FSES [Pokoleniye Z pokoleniye epokhi FGOS], 2017 [Electronic resource]. Available at: https://cyberleninka.ru/article/v/pokolenie-z-pokolenie-epohi-fgos.

[7] G. N. Akhmetzyanova, Z. Pronina, and A. O. Bagateeva, "Project Approach as a Means of Forming the Availability of Bachelors to Innovate Activity in Information Technologies", Tarih Kultur Ve Sanat Arastirmalari Dergisi-Journal of History Culture and Art. Research, 2018, 7 (4), pp. 428-434.

[8] M. S. Il'ina, A. M. Aydarova, and Ye. A. Khuzina, "Situational approach as one of the factors of effective formation of communicative culture of students in foreign language classes in higher education", Global scientific potential, 2016, 3, pp. 15-17 [Electronic resource]. Available at: http://globaljournals.ru/assets /files/journals/global-scientific-potential/60/g-n-p-3(60)-main.pdf.

[9] A. P. Panfilova, "Interaction of participants of educational process: tutorial and workshop for undergraduate academic", Moscow: Yurayt Publishing House, 2017, 487 p.

[10] R. G. Sakhieva, E. R. Khairullina, L. G. Khisamiyeva, N. S. Valeyeva, A. R. Masalimova, and V. G. Zakirova, "Designing a structure of the modular competence-based curriculum and technologies for its implementation into higher vocational institutions", Asian Social Science, 2015, 11 (2), pp. 246-251.

[11] Obrazovatel'nyy forum, 2019 [Electronic resource]. Available at: https://www.goethe.de/ins/ru/ru/spr/eng/dez/kon.html.

[12] N. Ye. Koroleva, F. KH. Sakhapova, and N. A. Chernova, "Educational aspect in teaching a foreign language at the university", Personality, family and society: pedagogy and psychology: collected papers, Novosibirsk: SibAK, 2017, no. 3 (72), pp. 19-23.

[13] G. N. Akhmetzyanova, "Information Competence Structure and Content of the Higher School Students", Mediterranean Journal of Social Sciences, 2015, 6, 2 S3, pp. 254-259.

[14] A. O. Bagateeva and G. N. Akhmetzyanova, "Modular Technology Of Foreign Language Training Of Technical University Students", Modern Journal of Language Teaching Methods, 2017, vol. 7, issue 9, pp. 507511. 
[15] A. O. Bagateeva and G. N. Akhmetzyanova, "Psychoeducational Support of Foreign Language Training in Higher School", Modern
Journal of Language Teaching Methods, 2017, vol.7, issue 12, pp. 178182. 